\title{
収縮、蛋 白*
}

\section{柴田宣 彦** 和 田昭**}

脂質沈着を伴う動脈壁の局所的肥厚, 膨隆によ る血管腔の狭小化を来す動脈病変が粘状硬化症と 解せられるが, 籿状硬化巣の進展を組織学的にみ ると，すでに明らかにされているょうに，本症の 発生初期, 細胞質内に脂肪滴を有するいわゆる泡 沫細胞 (foam cell) が動脈内膜に必発的にみられ るとともに，該細胞はやがてその数を増し，互い に集積する。 そして，それらの周辺を増生した Collagenや弾性繊維が取り团み, いわゆるFibrous Plaque が形成されて粥状硬化の進展をみる1). こ のような動脈の䉼状硬化病変の成立に一義的な役 割を果たす細胞として，近年動脈平滑筋細胞が強 調されるようになった ${ }^{2-5)}$ 。すなわち, 前述の泡沫 細胞が平滑筋細胞に由来する2)ことや，平滑筋細 胞は Fibrous Plaque の成立に関与する Collagen や弾性繊維の基本物質である Elastin を産生し分 泌する機能の女ること1)などが明らかにされてき たからである. 動脈平滑筋細胞も筋細胞である以 上，収縮性蛋白を有し ${ }^{6,7)}$ ，その作動により収縮， 弛緩が行われるのは当然と思われるが，この細胞 の微細構造は骨格筋や心筋の細胞と異なって横紋 構造を示さないしたがって収縮蛋白のミオシン (My) やアクチン (Ac) の細胞内局在を横紋筋細 胞に拈けるようには直ちに同定できないし，その 性状や細胞としての運動性にも横紋筋とは異なっ た特性があるかもしれない，本論文では，まず動 脈中膜より抽出された収縮性蛋白の性状，その特 性を検討した後，動脈平滑笳細胞内での本物質の 存在を電顕的に同定する. かくて該細胞が運動性 を有することの根拠を得た後, 本細胞の運動性と

*1975年 5 月第 6 回日本動脈硬化学会に括いて発表.

**大阪府立成人病センター
粥状硬化症進展との関連につき考察するととも に, 粥状硬化症の進展に伴 弓動脈収縮蛋白の性状 の変化につき検討した結果を述べる.

\section{実 験方法}

\section{1. 動脈中膜より抽出された収縮性蛋白の性状 に関するもの}

健常動脈として馬および牛の頸動脈および死後 10時間以内に剖検した15歳以下の人の大動脈で, 肉眼的に全く異常のみられないものを選んだ. 粥 状硬化を有する動脈は, 死後 10 時間以内に剖検し 得た成人の大動脈を材料とした。該大動脈は; 剔 出後直ちに室温で, 生食水で洗浄した後, (1) 内 膜面に Fatty Streak以上の肉眼的䋆状硬化病変を 認めない一見健常にみ光る部分, (2)肉眼的にFatty Streakのみが認められる部分, (3)肉眼的にFibrous Plaque 末での変化はみられるが，石灰化や出血性 変化などComplicated Lesionを除く部分（場合に より(2)拉よび(3)をSclerotic Lesion と統括）を研 究材料として用いた。

(1) 収縮蛋白の抽出：材料となる動脈の外膜 を除いた後，あらかじめー $18^{\circ} \mathrm{C} に$ 保った $50 \%$ グリ セリン液の中に $2 \sim 3$ 日間浸して保存した後, 蒸 留水でよく洗ってから, 文献6), 7)の方法に従っ $\tau \mathrm{Ca}^{2+}$ 感受性を有する収縮蛋白, ミオシン $\mathrm{B}$ ( $\mathrm{My}-\mathrm{B})$ を抽出し，これょり硫安分画法により粗 ミオシン（My）を得た。これらはさらに $0.5 \mathrm{M}$ KCl-15mM Tris-HCl buffer (pH7.4) に平衡さ せた Sepharose 4B カラムクロマトによって精製 された。すなわち，抽出した $\mathrm{My}-\mathrm{B}$ を $\mathrm{ATP}$, $\mathrm{MgCl}_{2}$, EGTA を含む高イオン強度液に溶解し, その遠心上清の上 $1 / 2$ を硫安処理し，40～70\%分 
動脈硬化 Vol. 4 No.1 April 1976

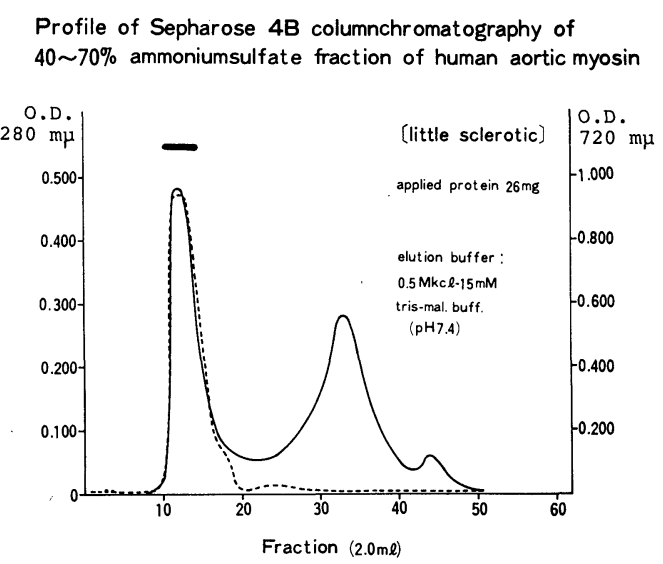

Fig. 1 人大動脈（硬化度 1) より抽出された 粗ミオシンの Sepharose 4B カラムク ロマトによる製精.

最初の O.D. $280 \mathrm{~m} \mu$ での吸光度(一)の ピークがO.D. $720 \mathrm{~m} \mu$ のピークに一致 するのでこの分画を精製 $\mathrm{My}$ として用 いた. 各分画の $0.2 \mathrm{ml}$ をとり， $10 \mathrm{mM}$ EDTA, $1 \mathrm{mM}$ ATP の存在下 $10 \mathrm{mM}$ Tris-mal. buffer (pH7.0) で37º, 5 分間反応. Martin-Doty 法で遊離した 無機燐を発色させ, O.D. $720 \mathrm{~m} \mu$ で吸 光度を測定プロットした $(\cdots \cdots)$.

— O.D. $280 \mathrm{~m} \mu, \cdots \cdots:$ O.D. $720 \mathrm{~m} \mu$

画の沈降物を $0.5 \mathrm{M} \mathrm{KCl}$ を含む $15 \mathrm{mM}$ Tris- $\mathrm{HCl}$ buffer (pH7.4) に透析した後上述のカラムにかけ る. Elution Pattern は Fig. 1 に示すごとくで, My に特徵的な EDTA で活性化される ATPase 活性は最初に溶出される蛋白分画に一致するの で，この分画を集め，0.05M KCl（pH7.0）に対 して透析, 沈澱物を集め $0.6 \mathrm{M} \mathrm{KCl}$ に溶解し精 製 My を得た.アクチン（Ac）は文献7）に従 い, あらかじめ Guba-Straub 液で homogenate し My を抽出した後の動脈細片のアセトン粉末 より調製した.グリセリン処理により動脈内膜は 溶解するので収縮蛋白の抽出は必然的に中膜組織 よりなされたことになり，この場合も中膜を構成 する主たる細胞は平滑筋細胞である. 粥状硬化 症を有する動脈の場合, 収縮蛋白の抽出（就中, $\mathrm{My}-\mathrm{B}$ 拈よび $\mathrm{My}$ の場合）に際し注意すべきこと は，抽出液での homogenation のときに混入す る脂質の除去である．脂質の混入の大きな場合， 収縮蛋白が当然沈降すべき条件でも沈降せず，そ
のため分離抽出が活とんど不可能に近いことがあ るので, homogenate の遠心上清の最上層に集ま る脂質を精力的に除去するとともに，上清を十分 氷冷した後, ガラス filter を通して混入する脂質 をできるだけ除いてから次の抽出操作に移ること が必要である.

(2) Sodium-dodecyl sulfate (SDS)-polyacrylamide gel electrophoresis: 抽出され た蛋白ならびに動脈細片を文献 8 の手法に従い Urea 拉よび Sodium dodecil sulfate (SDS) 混 液で溶解して電気泳動し解析するとともにWeber -Osborn の手法 ${ }^{8}$ に従って泳動 band の分子量を 概算した。

(3) 動脈以外からの収縮蛋白：馬骨格筋, 心 筋, 血小板からの収縮蛋白は文献 7，9，10 亿記 載の方法により調製した。

(4)収縮蛋白の性状に関する寒験方法：抽出 された収縮蛋白は Huxley の negative staining 法 ${ }^{111}$ により電顕的に観察するとともに，その超沈 浅活性を江橋の開発した濁度法 ${ }^{12}$ )で，ATPase 活 性を Martin-Doty 法 $^{13)}$ により測定した。

(5)その他： 蛋白量の測定は牛血清アルブミ

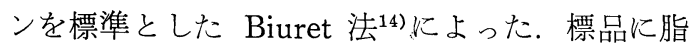
質の混入が多いと白濁して測定が困難なため遠心 による除去を必要とする。使用した試薬は分析用 のもので, 水は再蒸留水を用いた.

\section{2. 動脈平滑筋細胞, その他の動脈壁細胞にお} けるアクチン，ミオシン同定方法

家兔骨格筋 My より私共の方法7, 10,15) により haevy-meromyosin (HMM) を作製した後，動 脈片をあらかじめ50\%グリセリン液で12～16時間 処理後, $0.1 \mathrm{M} \mathrm{KCl}, 5 \mathrm{mM} \mathrm{MgCl}_{2}, 10 \mathrm{mM}$ Tris$\mathrm{HCl}$ buffer (pH 7.4) で洗浄, 段階的にグリセ リンを除いた後，石川の方法 ${ }^{16)}$ に従って HMM と反応せしめた後, 電顕用超薄切片を作製7), HMM-Ac 結合体が示す特徵的な矢尻状構造物を 日立100-B電子顕微鏡により観察した．My の細 胞内同定は牛腎動脈平滑筋細胞で, 牛頸動脈から 前述の方法で精製した $\mathrm{My}$ の抗体を作製し, peroxidase 標識抗体電顕法 ${ }^{18)}$ (間接法)により行っ

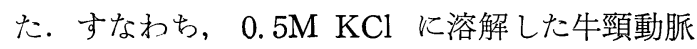


My ( $4 \sim 5 \mathrm{mg} / \mathrm{ml})$ を等量の Complete Freund's Adjuvant に㲘濁し, 週 1 回の割で家忽背部皮下 に注射 ( 1 回注射蛋白量 $6 \sim 9 \mathrm{mg}$ ), $7 \sim 8$ 回の 注射により家克で抗血清を作製した。これより抗 体活性を有する IgG を硫安分画法およびDEAECellulose カラムクロマト法により分離精製し動 脈 $\mathrm{My}$ の 1 次抗体として使用した，一方，家兔 IgG に対する山羊の抗血清から IgG を分離精製 し, peroxidase を標識したものを購入 (医学生物 学研究所, 名古屋) しこれを 2 次抗体として使用 した．抗原抗体反応は Difco 製精製 Agar を0.4 $\mathrm{M} \mathrm{KCl}-0.01 \mathrm{M}$ 燐酸力リ buffer (pH7.4)で $1 \%$ に溶かしたものを用い, Ouchterlony 法19)による Gel 拡散法によって行った. peroxidase 標識 2 次 抗体と家兔 $\operatorname{IgG}$ との免疫反応は，後者を電気泳 動した後, 前者と反応させ（免疫電気泳動では1 オン強度 0.05 の Veronal buffer で作った $1 \%$ Agar を用いて実施), 生じた沈降線に対し, Graham-Karnovsky の方法 ${ }^{20)}$ 適用して peroxidase 反応を行い, peroxidase 標識 2 次抗体々 しての特異性を検討した. 牛の腎動脈片をカミソ リで可及的小さな細片とした後，1\% glutaraldehyde-1\% paraformaldehyde により固定，10\% 庶糖- $10 \mathrm{mM}$ 燐酸 $\mathrm{Na}$-buffer(pH7.0) を含む生食 水で洗浄後, 1 次抗体 $(25 \mathrm{mg} / \mathrm{ml})$ を $8^{\circ} \mathrm{C}$ の 48 時間作用せしめ, 以後鈴木の方法 ${ }^{18)}$ により処 理 し, 酵素標識抗体電顕法 (間接法) により動脈平 滑筋細胞内での peroxidase 反応陽性部位を観察 した. 1 次抗体の代わりに, 動脈 $\mathrm{My}$ で感作しな い無処置家鬼の血清より分離精製した IgGを用 い同様に処理したものを対照とした．また，2次 抗体のみ，およびあらかじめ動脈 $\mathrm{My}$ で吸収せ しめた 1 次抗体の遠心上清を 1 次抗体の代わりに 用いたものも対照とした.

\section{3. 動脈平滑筋細胞の運動性と粥状硬化症の発 症，進展に関するもの}

体重約 $2 \mathrm{~kg}$ の雄性家兔 30 羽を用い，1 羽当たり 固形普通食にコレステロール $1 \mathrm{~g}$ と焼鷄卵 1 個と を加えた食餌を経口的に連日投与し，投与開始 後, $1,2,3,7,9,10,20,30,40,140$, 182 日目に屠殺, 胸部大動脈についてへスト:キシ
リン・エオヂン染色，ズダンIII染色を行い光学顕 微鏡的に, 主として内膜打よび中膜に打ける平滑 筋細胞の動態に焦点を合わせ観察した。 また同じ 部位の動脈片を屠殺後直ちに $2.5 \%$ グルタールア ルデヒドで固定, 以後成書の教えるところに従っ て ${ }^{17)}$ 超薄切片を作り, 酢酸ウラニールで後染色, 日立100-B電子顕微鏡を用い, 主に内膜, 中膜の 平滑筋細胞の動態を観察した。

\section{実 験 成 績}

\section{1. 抽出された動脈収縮蛋白の性状}

(1) 健常人大動脈の収縮蛋白：全く健常な動 脈組織として選ばれた15歳以下の人大動脈より既 述の方法で得られた収縮性蛋白 $\mathrm{My}-\mathrm{B}$ の超沈測 活性は牛頸動脈 $\mathrm{My}-\mathrm{B}$ のもと同じく中性付近 の低イオン強度塩溶液下で, 一定量の $\mathrm{Ca}^{2+}, \mathrm{Mg}^{2+}$ 存在の下, 低濃度の ATP の添加によって超沈測 を来す、この活性は $\left[\mathrm{Ca}^{2+}\right]$ のわずかの変動によ

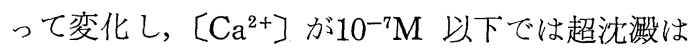
みられず，筋の弛緩に相当する透明化が括こり，

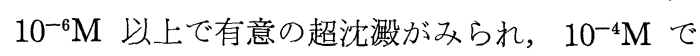
最大であった。 また同様の低イオン強度下で $\mathrm{ATP}, \mathrm{Ca}^{2+}$ 濃度が一定では, 超沈測活性は $[\mathrm{Mg}$ ${ }^{2+}$ ]に依存的で $1 \mathrm{mM}$ 以下では有意の超沈測はみ られず，10〜 $15 \mathrm{mM}$ の時最大活性が得られた．以 上の超沈港预よび ATPase 活性に対する $\mathrm{Ca}^{2+}$, $\mathrm{Mg}^{2+}$ の影響は, すでに報告した牛頸動脈 $\mathrm{My}-\mathrm{B}$ 6,7) のものと同一で，その比活性に多少の違いは あって子基本的性状は人大動脈 $\mathrm{My}-\mathrm{B}$ との間に 差異はみられないものと考えられる. 本標品の高 イオン強度下における negative staining 法によ る電顕像は Fig. 4 と同じで, Huxley が筋収縮蛋 白の特徵的な電顕学的構造として示したいわゆる “矢尻状構造”を示す。すなおち, 高イオン強度 下において単分子に解離した My が，フィラメン 卜状のAck一定の極性を的て矢尻状に付着し て生じたものと解せられているもので，すでに私 共が牛頸動脈 ${ }^{6,7)}$ や白血球, 血小板などの $\mathrm{My}-\mathrm{B}^{9}$ について示したものと全く同一の構造である.こ の $\mathrm{My}-\mathrm{B}$ から $\mathrm{My}$ を分離, 精製して $8 \mathrm{M}$ Urea を含む SDS で溶解し，5\% polyacrylamide gel で電気泳動を行うと Fig. 2 の pattern が得られ 
動脈硬化 Vol. 4 No.1 April 1976
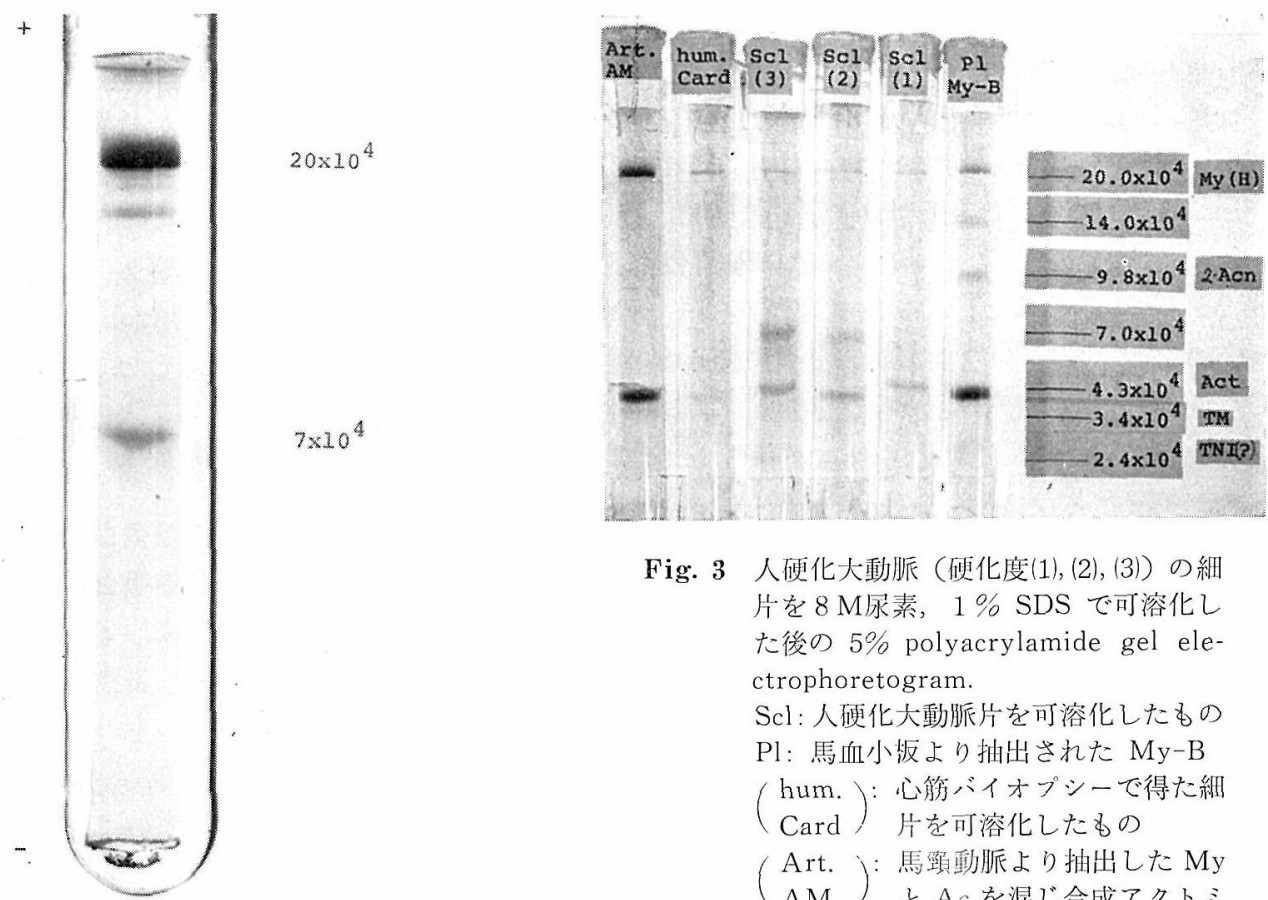

Fig. 3 人硬化大動脈（硬化度(1),(2),(3)）の紐 片を $8 \mathrm{M}$ 尿素， $1 \% \mathrm{SDS}$ で可溶化し た後の $5 \%$ polyacrylamide gel electrophoretogram.

$\mathrm{Scl}$ : 人硬化大動脈片を可溶化したもの $\mathrm{Pl}$ ：馬血小饭より抽出された $\mathrm{My}-\mathrm{B}$ (hum.)：心筋バイオプシーで得た細 Card）片を可溶化したもの (Art. )：馬頸動脈より抽出した My (AM) とAc 㕝混じ合成アクトミ オシンとしたもの

Fig. 2 健常な人大動脈より抽出精製 されたミオシンのSDS-polyacrylamide gel electrophoretogram $\alpha$-Acn : $\alpha-$ アクチニン, Act: アクチン, TM:トロポミオシン. TN(I):卜ロポ ニンの中の TN-I 成分

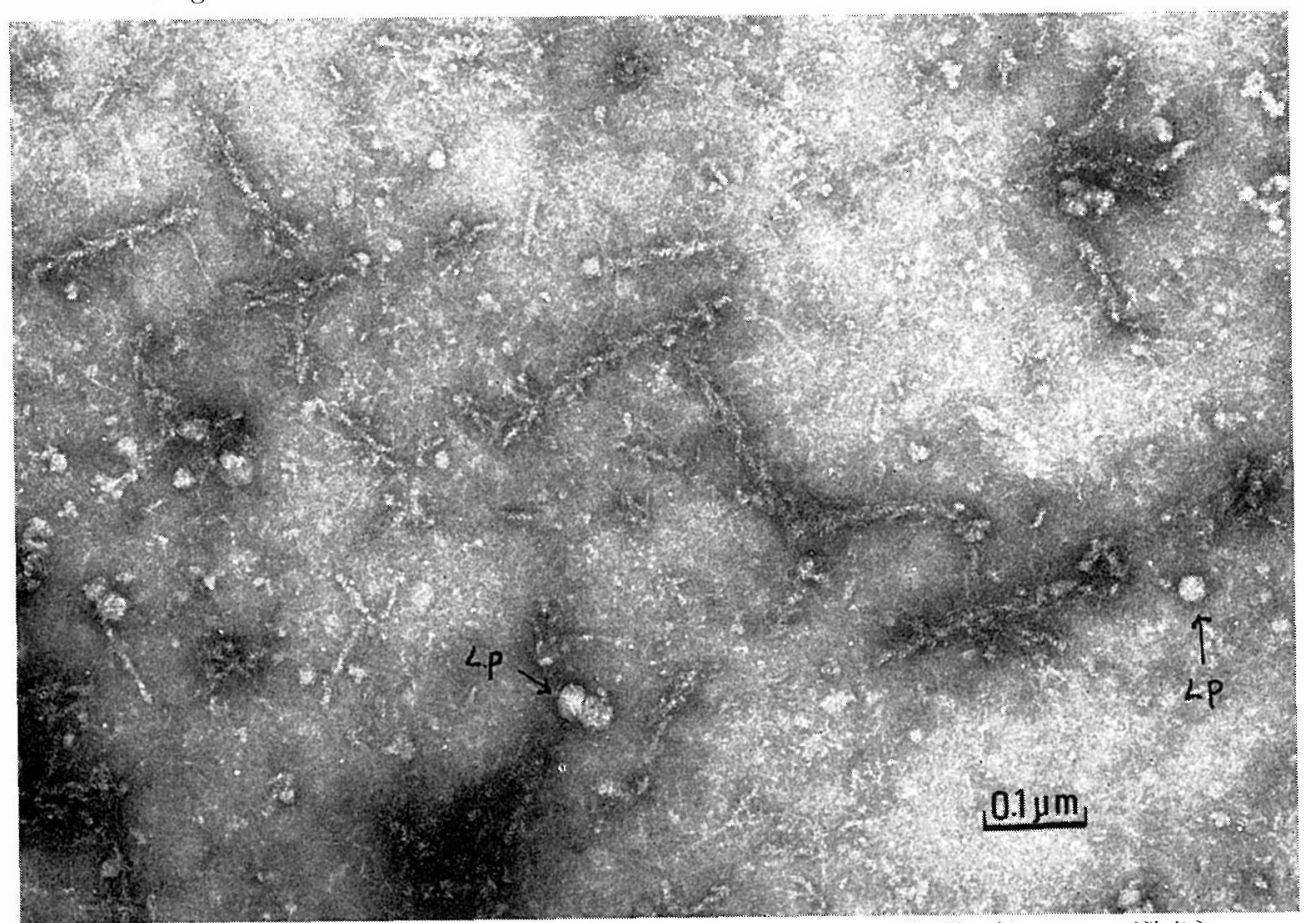

Fig. 4 人硬化大動脈（硬化度 $2 ， 3$ ）より抽出したミオシンBの電顕像（ネガティブ染色） イオン強度: 0.5 , 蛋白量 $0.20 \mathrm{mg} / \mathrm{ml}$ LP: リポ蛋白のネガティブ染色像 


\section{Superprecipitation of myosin B from human aortic media and intima ( $8 \mathrm{hrs}$ after death) in the presence of $0.1 \mathrm{mM}$ ATP}

$\Delta$ O.D. $660 \mathrm{~m} \mu$

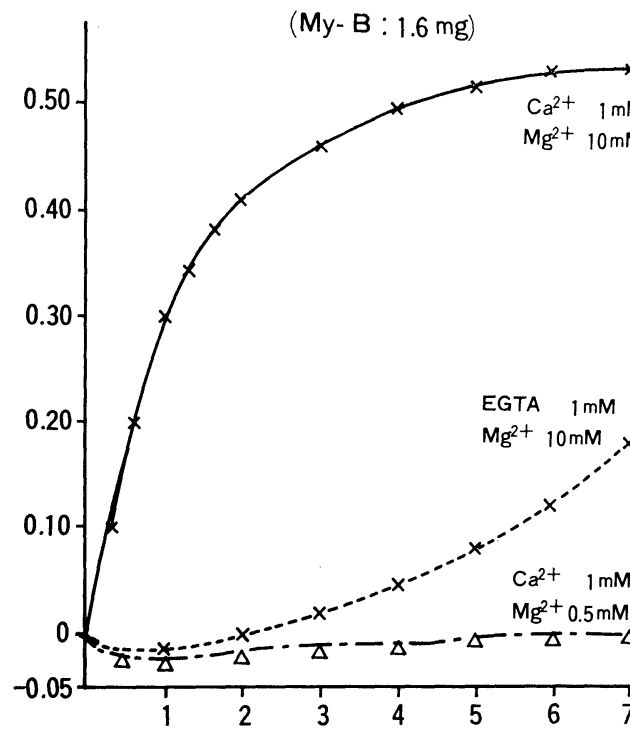

[B]

(My-B: $2.2 \mathrm{mg})$

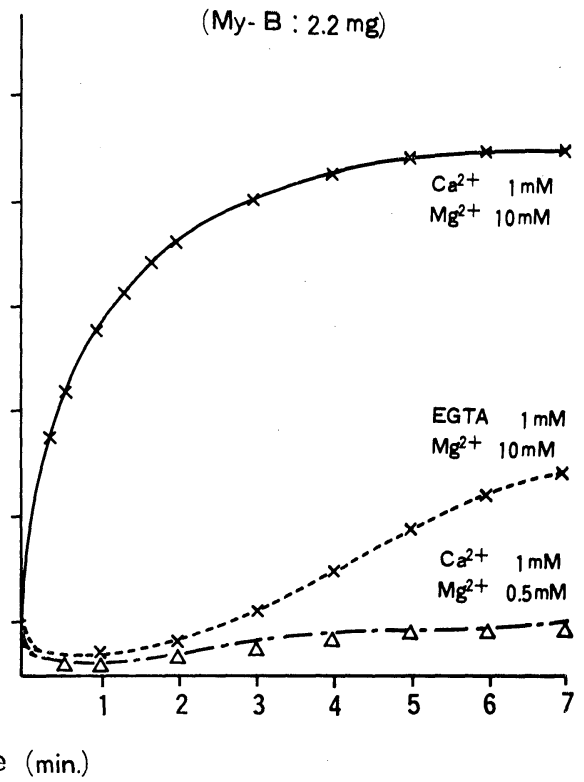

Fig. 5 人硬化大動脈より抽出したミオシンBの超沈澱.

〔A]：硬化度(1)のもの〔B]：硬化度(2)拉よび(3)のもの

$10 \mathrm{mM}$ Tris-maleate buffer ( $\mathrm{pH} 7.0), 0.1 \mathrm{mM}$ ATP 添加で反応開始, 吸光度 $660 \mathrm{~m} \mu$ での吸光度の变化で測定. 蛋白量 $0.5 \mathrm{mg} / \mathrm{ml}$.

$\times — \times: 1 \mathrm{mM} \mathrm{Ca}^{2+}, 10 \mathrm{mM} \mathrm{MgCl}$ 存在のもの

$\times \cdots \cdots \times: 10 \mathrm{mM} \mathrm{MgCl}, 1 \mathrm{mM}$ EGTA 存在のもの

$\triangle \longrightarrow \triangle: 1 \mathrm{mM} \mathrm{Ca}^{2+}, 0.5 \mathrm{mM} \mathrm{MgCl}_{2}$ のもの

た. 分子量 $20 \times 10^{4}$ のものは My の heavy chain に相当すると考光られる. light chain に相当す る低分子のものはみられなかった. 分子量 $7 \times 10^{4}$ のものは，その本態はよく判らないが fibroblast の My の電気泳動図でみられる微小管の構成蛋 白 tublin 様の混在 ${ }^{21)}$ によるものではないかと思 われる.この泳動像は馬の動脈，血小板の精製 My の泳動像と差異を認めない（骨格筋のものと は多少異なる)。つまり，人大動脈 $\mathrm{My} \& \mathrm{Mg}^{2+}$ に対する感受性, 電気泳動上の pattern, My 重 合体の電顕像 6 , 7) など牛頸動脈の $\mathrm{My}$ ならびに平 滑筋型 $\mathrm{My}$ をもつ血小板や白血球の $\mathrm{My}^{9,10,23)}$ 本質的に同様のものと考兄られる.

(2) 粥状硬化のある人大動脈の収縮蛋白： 外 膜を除いた大動脈を粥状硬化の程度により方法の
項で述べたように(1),(2),(3)に分け，それぞれの組 織片約 $0.2 \mathrm{~g} 0.3 \mathrm{mM} \mathrm{NaHCO}$ 液でhomogenize し, 8M Urea を含む $1 \%$ SDS で溶解し， $5 \%$ polyacrylamide gel electrophoresis を行うと Fig. 3 のような pattern が得られた。 これより明 らかなごとく，少なくともFibrous Plaqueまでの 病変部では $\mathrm{My}, \mathrm{Ac}$ などよりなる収縮蛋白が肉眼 的に健常な部位と同等に存在することが判る。し かもそれらの分子量は人心筋, 馬の頸動脈, 血小 板等の $\mathrm{My}, \mathrm{Ac}$ のものと差異がない。しかし, 分子 量 $7 \times 10^{4}$ のもの(混入した tublinに相当か? ${ }^{21)}$ )は 硬化度の進行とともに増加する傾向がみられた。 硬化度(2), (3)の部分から抽出した $\mathrm{My}-\mathrm{B}$ の高イオ ン強度下での電顕像は Fig. 4 のごとくで, リポ 蛋白とみられるもの 22 の混在はあるが，部分的に 
動脈硬化 Vol. 4 No.1 April 1976

Table 1 人硬化大動脈より抽出したミオシンBの ATPase 活性 $\left(\mathrm{Ca}^{2+}\right.$ の有無による影響 $)$

2) little sclerotic (硬化度(1))の部分か らのbの

3) sclerotic（硬化度(2), (3))

\begin{tabular}{l|r|r|c}
\hline & $\begin{array}{r}\mathrm{Ca}^{2+} \\
(1 \mathrm{mM})\end{array}$ & $\begin{array}{r}\mathrm{EGTA} \\
(1 \mathrm{mM})\end{array}$ & $\begin{array}{c}\mathrm{Ca}^{2+} \\
\mathrm{EGTA}\end{array}$ \\
\hline 1) equine carotis & $\begin{array}{r}0.048^{*} \\
\pm 0.010\end{array}$ & $\begin{array}{r}0.015^{*} \\
\pm 0.008\end{array}$ & 3.2 \\
\hline 2) little sclerotic area & $\begin{array}{r}0.032^{*} \\
\pm 0.015\end{array}$ & $\begin{array}{r}0.018^{*} \\
\pm 0.012\end{array}$ & 1.8 \\
\hline 3$)$ sclerotic area & $\begin{array}{r}0.025^{*} \\
\pm 0.014\end{array}$ & $\begin{array}{r}0.021^{*} \\
\pm 0.013\end{array}$ & 1.2 \\
\hline
\end{tabular}

* $\mu$ moles $\mathrm{Pi} / \mathrm{mg}$ prot. $/ \mathrm{min} .\left(37^{\circ} \mathrm{C}, 5 \mathrm{~min}\right.$.) reaction mix.: $0.1 \mathrm{mM}$ ATP, $10 \mathrm{mM} \mathrm{MgCl}_{2}$, 0. $05 \mathrm{M} \mathrm{KCl}, 10 \mathrm{mM}$ tris-mal. buff. ( $\mathrm{pH}$ 7.0)

yield of myosin-B:

1): $6.0 \mathrm{mg} / \mathrm{g}, 2): 2.1-3.2 \mathrm{mg} / \mathrm{g}, 3): 1.3-$ $2.0 \mathrm{mg} / \mathrm{g}$
Table 2 人硬化大動脈より抽出精製したミオシ ンの ATPase 活性.

2) little sclerotic area（硬化度(1))の 部分より抽出したもの

3） sclerotic area（硬化度(2)(3)）の部 分より抽出したもの

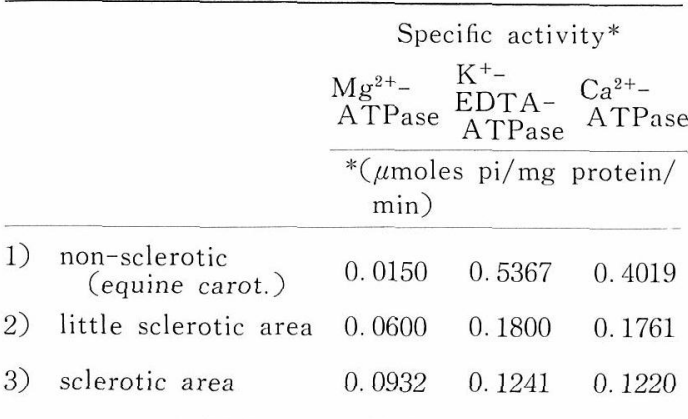

reaction mix.: $5 \mathrm{mM}$ ATP, $0.5 \mathrm{M} \mathrm{KCl}, 10 \mathrm{mM}$ tris-mal. buff. ( $\mathrm{pH}$ 7.0), (+) or $(-) 10 \mathrm{mM} \mathrm{MgCl}, 10 \mathrm{mM}$ EDTA, $10 \mathrm{mM} \mathrm{CaCl}_{2}$. $37^{\circ} \mathrm{C}, 5 \mathrm{~min}$.

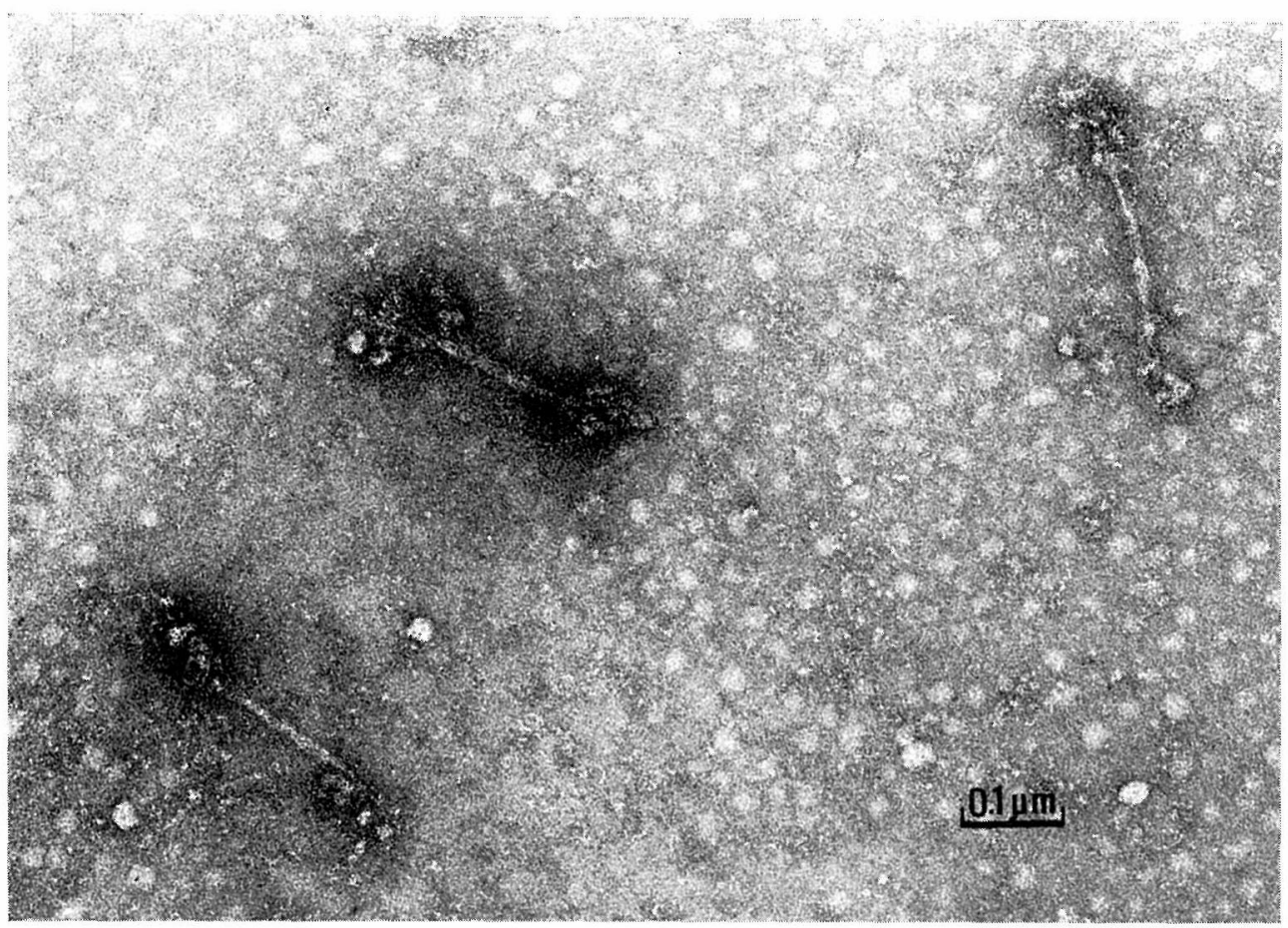

Fig. 6 人硬化大動脈(硬化度 2,3 部分)より抽出したミオシン会合体の電顕像(ネガティブ染色) イオン強度: 0.1 , 蛋白量: $0.1 \mathrm{mg} / \mathrm{ml}$ 
は健常部 $\mathrm{My}-\mathrm{B}$ のものとほぼ同様の矢尻状構造 物がみられる。この $\mathrm{My}-\mathrm{B}$ の超沈測活性をみる と Fig. 5 のごとくで，硬化度(1)のものとほぼ同様

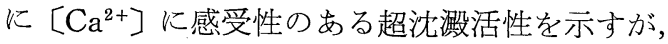

EGTA 存在下でも超沈澱がみられ. 健常のもの より $\mathrm{Ca}^{2+}$ 感受性は低下している。この条件下で の $\mathrm{My}-\mathrm{B}$ の $\mathrm{Ca}^{2+}$ の存否による ATPase 活性を 健常の馬動脈 $\mathrm{My}-\mathrm{B}$ と比較してみると Table 1 のごとくで，硬化度の進行につれて $\mathrm{Ca}^{2+}$ による 活性化の度の低下していることが知られる。この 所見は収縮蛋白の中 $\mathrm{Ca}^{2+}$ 受容体であるトロポニ

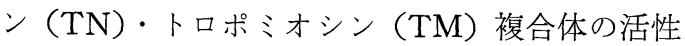
が硬化の進行につれ低下することを推測させる. 硬化度(1)抽よび(2)(3)の部分の $\mathrm{My}-\mathrm{B}$ から $\mathrm{My}$ 分離し，そのATPaseをみると Table 2 のごと くで, My-ATPase の特徽である $\mathrm{Mg}^{2+}$ で抑制,

$\mathrm{Ca}^{2+}$ 特よび EDTA で活性化という基本的な性 質は保有しているが，健常部のものに比し $\mathrm{Mg}^{2+}$ による抑制度は低く, EDTA よりも $\mathrm{Ca}^{2+}$ によ る活性化の方が大でその程度も健常部のものより 低いことが判る. しかしこの My（硬化度(2)(3)か らのもの）を低イオン強度下におくと健常部のも のと同様に polymer を作り，電顕的には Fig. 6 のごとく健常のものと同様の構造6,7) を示す。す なわち, 径は約 $150 \AA$ であるが横紋筋のものと異 なって両端にのみひげ状の突起を有し，長さは約 $0.3 \mu$ 之短く平滑筋の $\mathrm{My}$-polymer に特徵的な構 造を示9. 硬化(2)，(3)の部分から $\mathrm{TN} \cdot \mathrm{TM}$ 複合体 を含有するように室温で抽出した Ac および $\mathrm{My}$ B SDS-polyacrglamide gel electrophoresis に より解析すると, Ac の含量は硬化度の進行とと もに減じ，Ac，TM，TN 以外の成分の混入度の

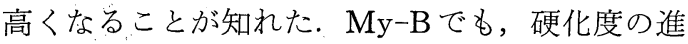
行につ积 Ac, My の heavy chainの含量の低下, およびカラムに進入せずカラム最上端に留る成分 の増加することが知られる. 今硬化度(1)打よび(2) (3)の部分から，それぞれ My 沶よびAc を抽出し， 両者をその由来部分に無関係に混合し， $\mathrm{Mg}^{2+}$ の存在下で $\mathrm{Ca}^{2+}$ の有無による $\mathrm{My} ・ A T P a s e の$ Ac による活性化をみると Fig. 7 のごとくで，硬 化度(2)(3)の部分からの Ac による $\mathrm{My}$ ・ATPase の活性化の程度は My の由来部分とは関係なく

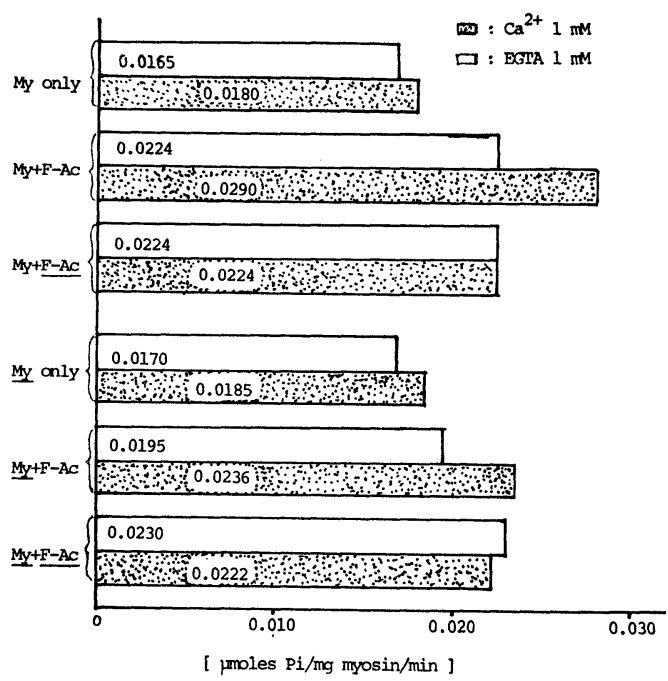

Fig. 7 人硬化大動脈より抽出したミオシン ATPase のアクチンによる活性化. reaction mixture:

$10 \mathrm{mMTris}-$ maleate $\operatorname{buffer}(\mathrm{pH}$ 7.0) $10 \mathrm{mM} \mathrm{MgCl}, 0.1 \mathrm{mM}$ ATP with or without $1 \mathrm{mM}$ EGTA $(\square)$ and $1 \mathrm{mM} \mathrm{Ca}^{2+}$ (IMini) reaction: $37^{\circ} \mathrm{C}, 5 \mathrm{~min}$.

$\mathrm{My}, \mathrm{F}-\mathrm{Ac}$ : 硬化度(1)の部分より抽出し

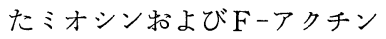

$\mathrm{My}, \mathrm{F}-\mathrm{Ac}$ ：硬化度(2)(3)の部分より抽出 したミオシン拉よび $\mathrm{F}$ ーアクチン

$\mathrm{Ca}^{2+}$ の有無による差がみられなかった。 また， $\mathrm{My}$ が硬化度(2)(3)の部分に由来する場合，その ATPase の Ackよる活性化は, 硬化度(1)の部分 からの Myのものに比し低值を示すことが判る. 以上の成績から, 硬化度(2)(3)の部分にも抽出可能 な $\mathrm{My} \cdot \mathrm{Ac}$ が存在すること, それらの活性は硬化 度の進行とともに低下寸るが，それは抽出時に混 入する非収縮蛋白成分の増大，つまり精製度の低 下によるものと推測される. また硬化度の進行に つれ, Ac に含有される $\mathrm{Ca}^{2+}$ 受容体, $\mathrm{TN} \cdot \mathrm{TM}$ 複合体の活性の低下が示された。

\section{2. 動脈平滑筋細胞における $\mathbf{A c} \cdot \mathbf{M y}$ の同定}

(1) Ac フィラメント： 硬化度(3)の部分に於 ける平滑筋細胞の電顕像はFig. 8のごとくで，核 は大きく，その周辺に Collagen（1) 繊維, 脂質 沈着を伴 5 . 細胞質内には Microfilament $(\hat{i})$ 女 


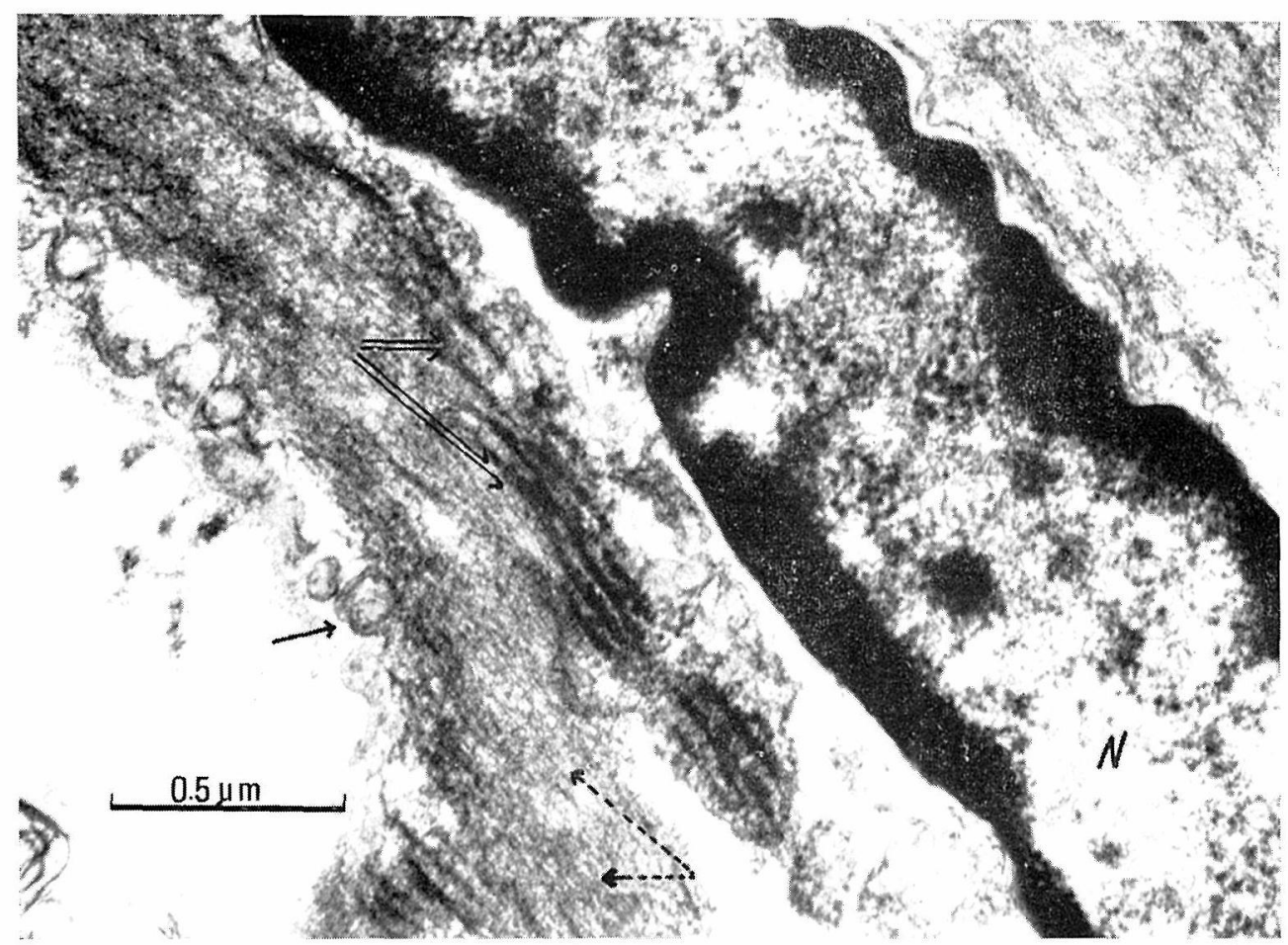

Fig. 8 人硬化大動脈（硬化度 1 の部分）平滑筋細胞の透過電虽像（強层大）

$\leftarrow$ pinocytotic vesicles, $\leftrightarrow$ microfilament

$\Leftarrow$ colagen fiber, $\mathrm{N}$ : Nucleus

みられるが，収縮蛋白繊維か否かよく判らない， また細胞膜に接して pinocytotic vesicles 様( 个) のものもみられる. 抽出された Acフィラメント の電顕像は文献 7 に示すものと同じで半ピッチが 約 $350 \AA$ の double helix 構造を示す径約 $80 \AA$ のつ ィラメントである。これに骨格筋 My より調製 L た HMM を反応させると, HMM が Ac フィラ メントに極性をもって付着 LFig. 4 と同様の特徵 的な矢尻状構造をとることが判る。この性質を応 用した石川の方法 ${ }^{16)}$ 用い，グリセリンで処理し た平滑筋細胞に HMM を反応させると, Fig. 9 の如く microfilament は毛ば立ち矢尻状にみ党る ようになる( 个)，この所見は健常牛動脈平滑筋細 胞にこの方法を適用した文献 7 ののと同様で, この所見から細胞内での AC 存在が確められた。

(2) My の細胞内同定：牛頸動脈 $\mathrm{My}$ の抗体 (家患 $I g G, 1$ 次抗体) 之 peroxidase で標識 し た家息 $I g G の$ の抗体（山羊- - IgG，2次抗体）を用 い，間接法による酵素標識電顕抗体法により牛動

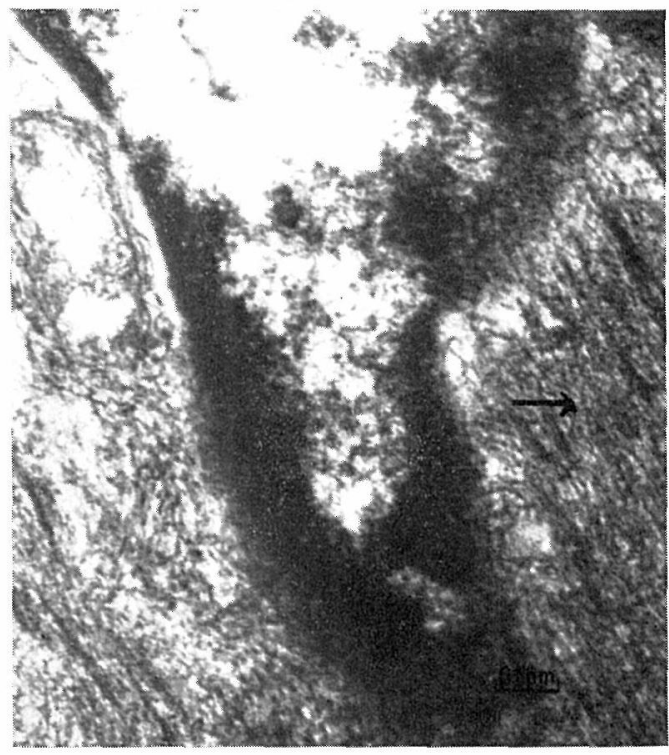

Fig. 9 人硬化大動脈(硬化度 1 ) の平滑筋細胞 （グリセリン処理したもの）に家患骨 格筋 HMM を反応させたものの透過 電顕像

— : 矢尼状構造らしくみ兄るもの 
収縮 蛋白

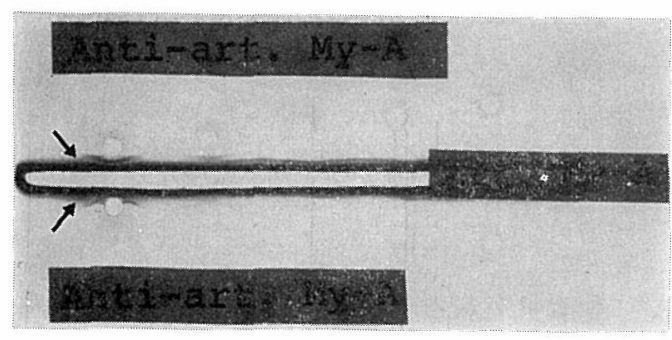

Fig. 10 牛覲動脈 My とその抗体 ( $\mathrm{IgG}$ との 抗原抗体反応 (オフタロニー法).

Art. $\mathrm{My}-\mathrm{A}$ : 動脈精製ミオシン

Anti-art. My-A：動脈精製ミオンン

の抗体

(家悉 $\operatorname{IgG}$ )

Fig. 11

牛健常晹間膜動脈での 動脈ミオシンン抗体によ 万免疫組織化学的電顕像 (peroxidase 標識抗体電 顕法一間接法).

上：抗体活性のない正常 家患 IgG で処理し た後 peroxidase 標 識 2 次抗体と反応さ せたもの（対照）

$D$ : dense body N: Nucleus

下: 動脈ミオンンの㧧体 と反応させた後, peroxidase 標識2次 抗体と反応させたも D

P: peroxidase 反応 隄性物

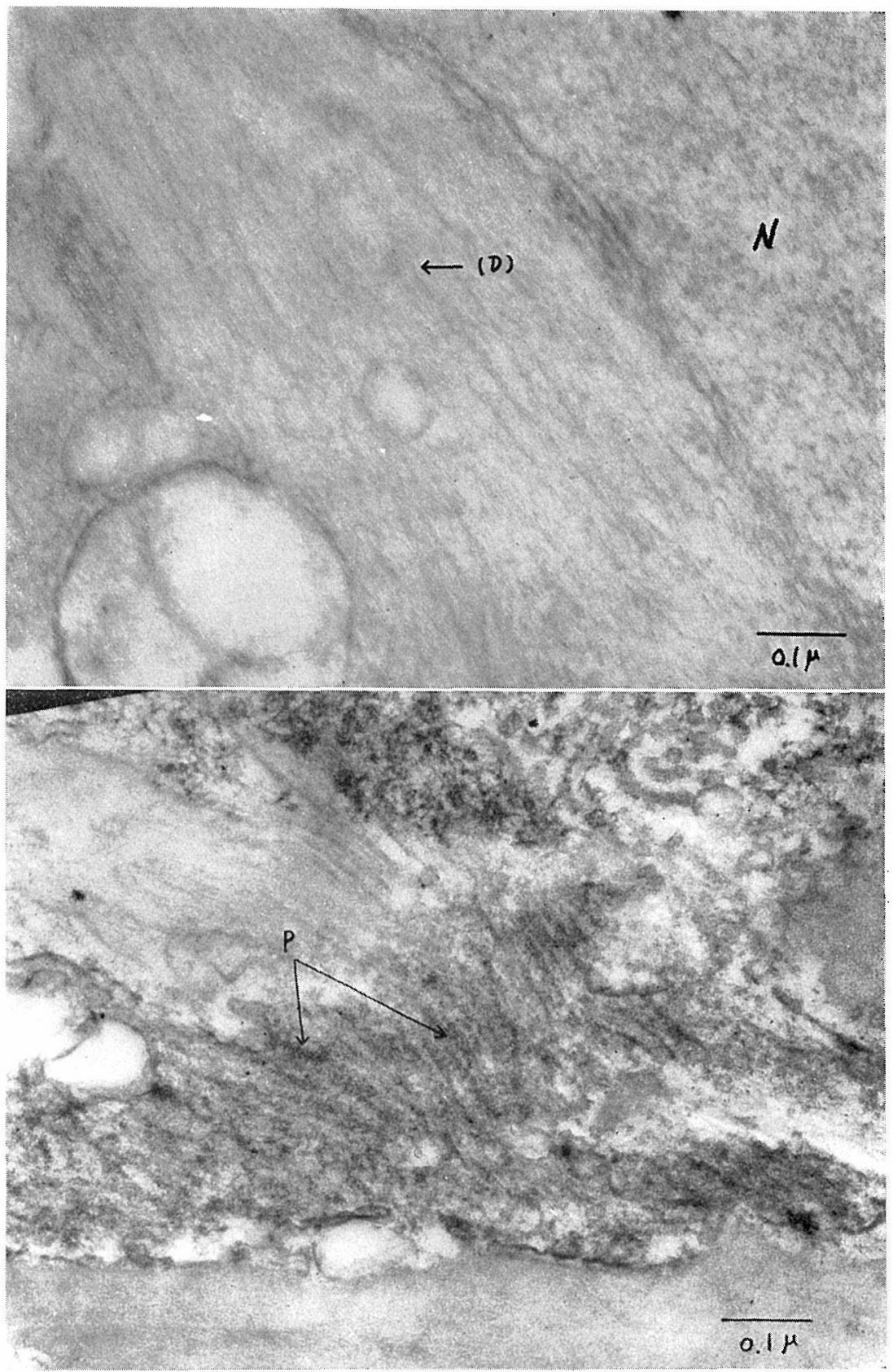


脈平滑筋細胞内の $\mathrm{My}$ の同定を試又た。Fig.10は 牛動脈 My とその抗体（家鬼 $\mathrm{IgG}$ ）との反応を才 フタロニー法を用いて検討したもので，単一な沈 降線が得られた $(\rightarrow)$. 一方牛動脈 $\mathrm{My}$ の抗体（家 鬼 $I g G)$ (1 次抗体) 扎よび，山羊圭用いて作製 し た家鬼 $\operatorname{IgG}$ の抗体（山羊 $\operatorname{IgG}$ ）に peroxidase を 標識したもの（2 次抗体）の抗原抗体反応を免疫 電気泳動図でみると単一の沈降線が得られ，これ は peroxidase 反応陽性であることが知られた。 かくて，グルタールアルデヒド・パラフォルムア ルデヒドで固定した動脈平滑筋細胞に 1 次抗体と して牛動脈 $\mathrm{My}$ の抗体( IgG) を反応せしめた後, 2 次抗体を反応せしめて peroxidase 発色反応を 行ったところ，Fig.11(下)のごとく平滑筋細胞内 のやや太い Microfilament に一致して反応陽性つ

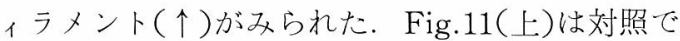
ある。以上の成績より，平滑筋細胞には横紋筋に みられるような規則正しい収縮性蛋白繊維の配列 はみられないが，Microfilament としてみられる 繊維のうち，細いものが Ac 繊維で，この数条に
つき一条ごとにやや太い My フィラメントが配列 している構造で収縮蛋白繊維が存在しているもの と解せられる。炎して Ac 繊維は所々に久られる いわゆる Dense bodyに付着しているようにみえ る.

3. 動脈平滑筋細胞の運動性と㑛状硬化発生進 展との関連

この研究は家鬼について行った。Fig.12はコレ ステロール負荷を行わない健常家鬼大動脈の光顕 像であるが，一層の内皮細胞下の内膜には皃とん ど細胞成分はみられない。内弾性板の深部，すな わち中膜には多数の平滑筋細胞が互いに相接して 存在しているのがみられる。しかもこれらは総じ て内膜面に並行して配列している，ところが潾状 硬化生成に関与するコレステロールをわずか 2 日 間負荷した家鬼大動脈では, Fig. 130ごとく,内膜 に細胞の増生がみられるとともに浮腫性変化，酸 性ムコ多糖類の増量, 脂質の沈着（ズダン染色陽 性）が証明される。この上うな変化は料状硬化初

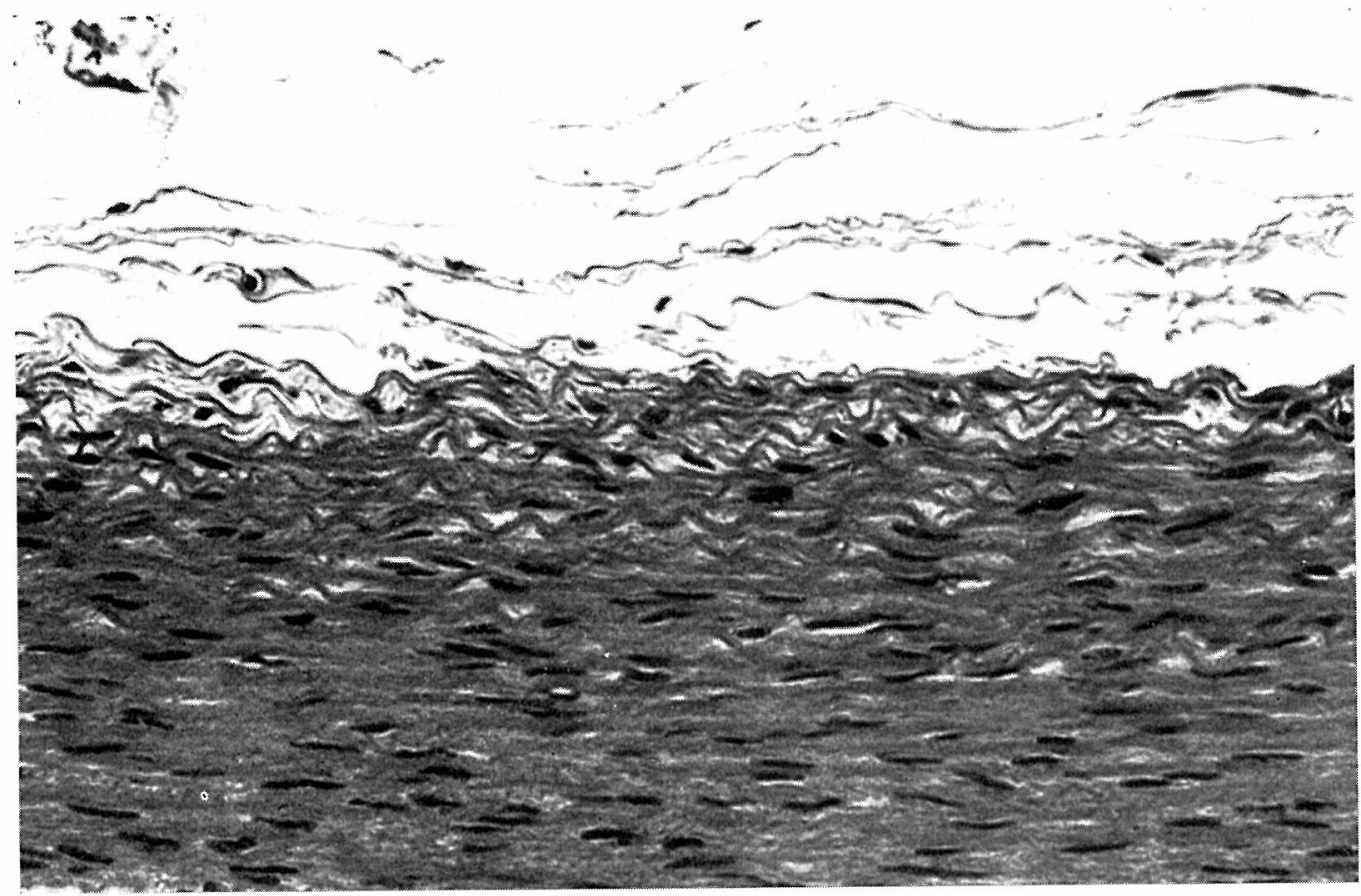

Fig. 12 健常家宒大動脈の光顕像（ヘマトキシリン・エオジン染色） $\times 200$ 


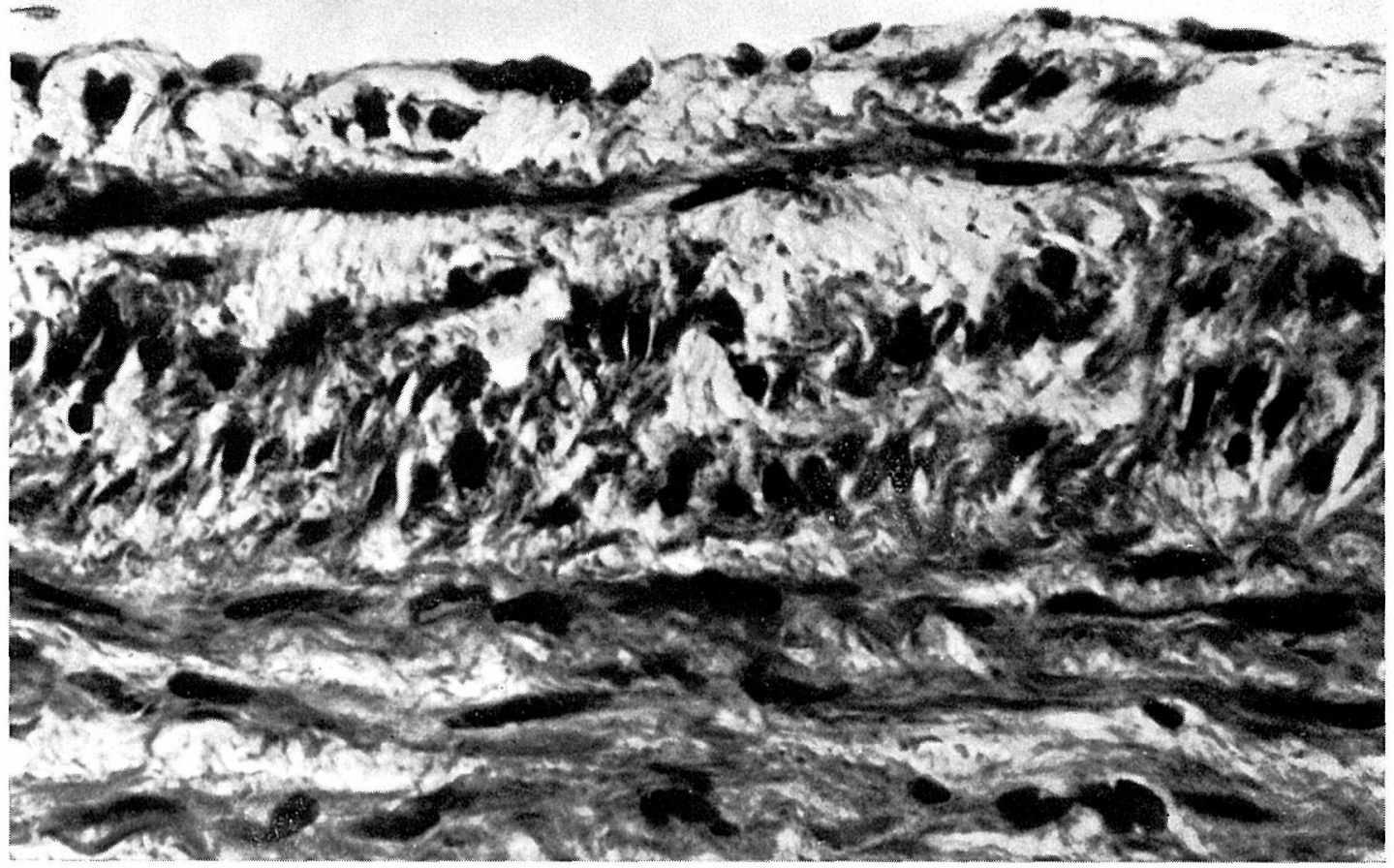

Fig. 13 コレステロール負荷 2 日目の家鬼大動脈の組織像（H.E. 染色）

$\times 400$

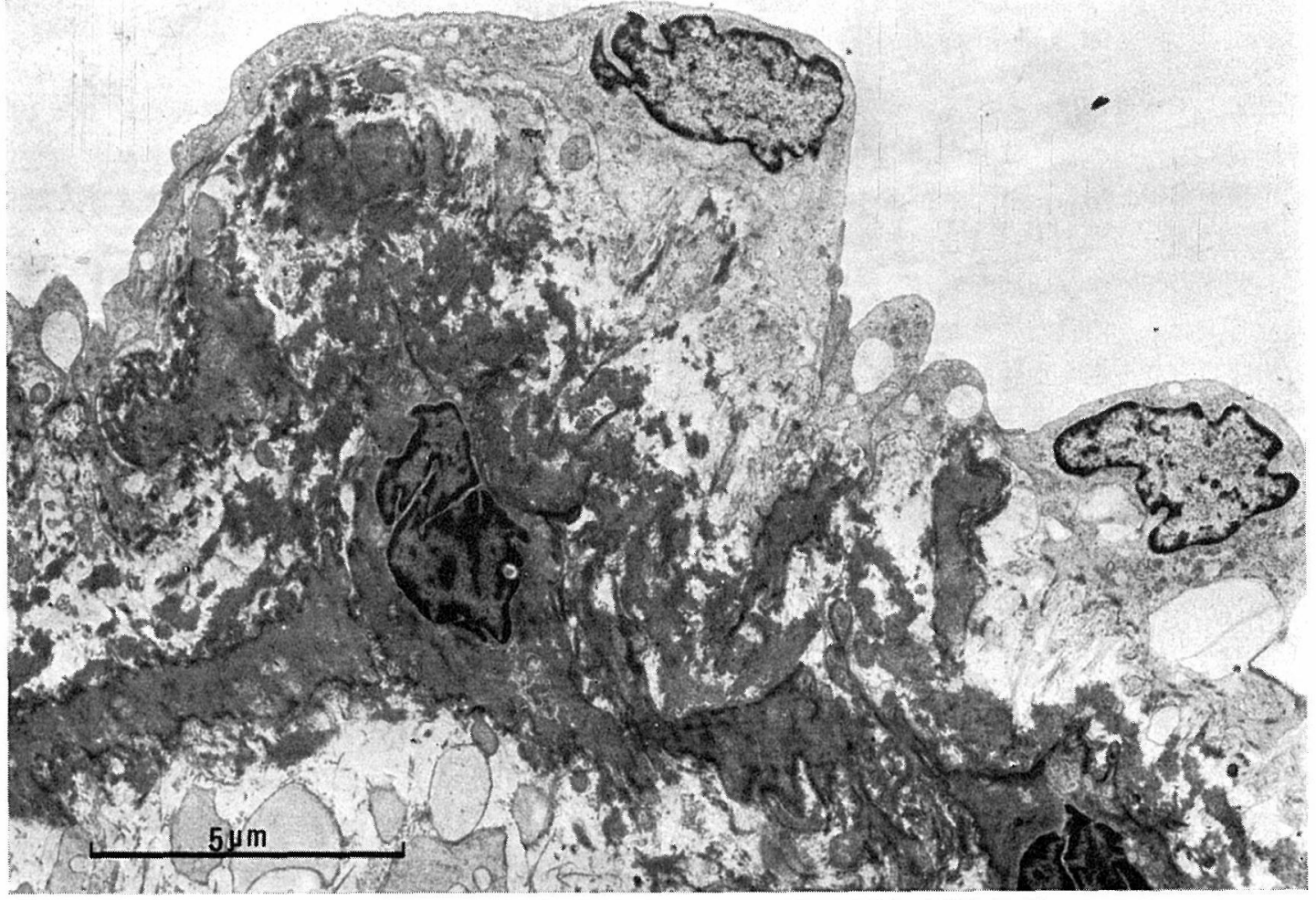

Fig. 14 コレステロール負荷 2 日目の家患大動脈内膜域の透過電顕像 


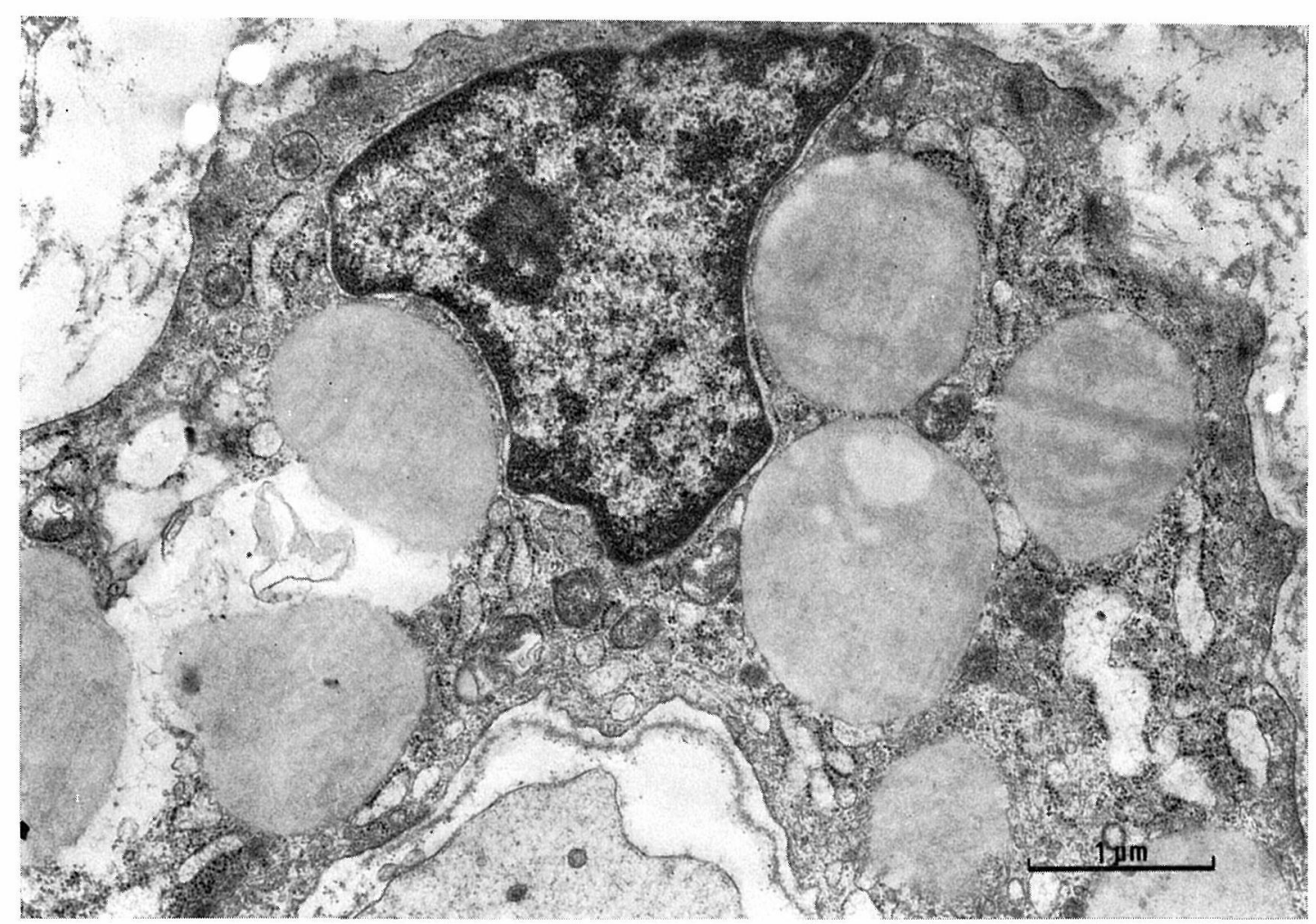

Fig. 15 コレステロール負荷家鬼大動脈に拈ける脂肪滴を取り込んだ細胞の透過電顕像

期像としてすでに捉えられているが，同様な変化 は中膜にもみられる，注目される点は内膜に近 い中膜の細胞，すなわち，中膜平滑筋細胞の配列 の変化である.これらは Fig. 12 ののと異なっ て, 個々の細胞が互いに解離し，かつ内膜の方向 に立ち上がり，内膜面に垂直に配列して，あたか も内膜の方に遊走しつつあるかのごとき像を示 す. Fig. 14 は，この時期に招ける内膜から内弾 性板にわたる部分に位置する細胞拉よび内皮細胞 の電顕像であるが，図中央にみられる細胞はその 長軸を内膜面に対し垂直とし，中膜から内膜に向 かって正に内弾性板を貫通しているかのごとき像 を示す。すなわり，この細胞の細胞膜および核膜 は波打って扣り，あたかも遊走中の白血球の姿に 似る。この細胞は，形態学的にみて中膜平滑筋細 胞のものと考えられる.これらの細胞のいくつか は細胞質内に空胞をもつようになるが，そのよう な細胞の電顕像をみると Fig. 15 のごとくで，そ の細胞質に大小の脂肪顆粒がみられる。この場合
前述の microfilament はこれら脂肪顆粒を取り囲 むように配列して拈り，あたか子脂肪滴を貧喰し て細胞質内に取り込んでいるか心印象老うける. このような細胞では，形態学的にはすでに平滑笳 細胞としての構造を失っているものもあって, macrophage 之の区別が困難なものが多いが, 少数の細胞では Collagen 繊維もみられ，平滑筋 細胞の特性も有しているので，これら細胞の起源 を平滑笳細胞としてもさしつかえなからう。これ らの像は，弹状硬化成因物質として食餌性にコレ ステロールを負荷した場合，血中脂質濃度の増加 に応じて動脈壁への脂質の浸透が起り。これとと もに内膜には水腫様膨化がみられるようになり， これを契機として内膜に近い中膜表層部に位置す る平滑筋細胞の細胞間結合がルーズとなり，あた かも遊離細胞のごとく内膜の方に向かい立ち上が り，その収縮蛋白の作動に上って内膜への遊走を 起しているものと解せられる。換言すれば脂質が 浸透した部位に向かって中膜平滑筋細胞は位置移 
動を起こし，内弾性板の間隙をも貫通し内膜へ集 積するとともに, 脂肪滴をも貧喰して fatty streak の形成に関与し，粥状硬化症の成立の基本的反応 を起すものと考兄られる。

\section{考案}

古く Anitschikow の時代, 家兔にコレステロ ールを負荷し，高脂血症を起こさせることにより 人の粥状硬化症のモデルとなりらる動脈病変が惹 起されることが明らかにされ24), 以来高脂血症と 继状硬化生成との関連は，ます屯す深いものとさ れてきた，そして近年では血中脂質のうち，low density lipoprotein (LDL), very low density lipoprotein (VLDL) の増大と码状硬化生成との 関連の大なることが強調されている. 血中 LDL は動脈壁に浸透し得ることが免疫組織学的にも明 らかにされているがここの結果いかなる機構によ って粥状硬化症が成立し進展していくかについて は近年ようやく動脈平滑筋細胞の関与が明らかに されつつある2)にすぎない：しかし，この場合も いかなる機序で平滑筋細胞が関与するようになる かについては未だ推測の域を出ない。私共は本研 究に打いて動脈平滑筋細胞に収縮性蛋白 $\mathrm{My}, \mathrm{Ac}$ がそれぞれフィラメント状に横紋筋とは異なった 配列の下に存在していることを明らかにするとと もに，その特性は主として My の側にあり，か つ遊走能を有する白血球の収縮蛋白に酷似するも のであることを過去の成績 $6,7,9,10,23)$ と相まって明 らかにした，かくて，動脈平滑筋細胞の運動性の 根拠をえたが，このような知見を念頭に扮いてコ レステロールを負荷した初期の家患大動脈の組織 反応をみると, 動脈内膜への脂質の浸透に呼応し てまず動脈中膜に位置する平滑筋細胞の細胞間結 合がルーズとなり，この細胞が脂質の浸入した内 膜に向かって立り上がり, あたかも遊走細胞のご とく運動性を発揮して遊走を始め, 内弾性板の間 隙を貫いて内膜へ位置移動を行うかのごとき像が 得られた.さらに内膜に遊走したこの細胞は，お たかも脂肪滴を貧喰して細胞質内に顆粒として保 持するごとく解せられる像も得た. 白血球の遊 走, 貧喰の機構として, その力の原動力が白血球 の収縮蛋白の作動に基づくことが強く示嗟されて

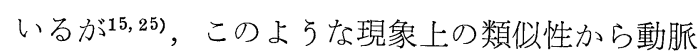
平滑筋細胞飞組織内に浸入した脂質を刺激源とし て遊走貧喰という細胞反応の発揮されるように収 縮蛋白の作動が励起されるものと考えたい，その 結果, 元来細胞成分の少ない内膜に平滑筋細胞の 集積が起こり脂肪滴の貧喰によって粥状硬化初期 病変としての泡沫細胞が形成される. そして, この細胞で生産, 分泌された Collagen 打よび Elastin によって Fibrous Plaque が形成されて本 症の進展がみられるものと解せられる. 組織培養 によって得た動脈平滑筋細胞を用いたSteinなど の成績22,26)によると，本細胞はリポ蛋白，とく に，LDL の取り込み能があり，それらはリソゾ 一ムに集積されるとともにリポ蛋白の蛋白成分を 異化し排出する能力のあることが明らかにされて いる.さらに VLDL とその remnantは本細胞に よる取り込みを助長する27)という。かくて LDL, 扣よびVLDLの料状硬化発症因子としての役割 も首肯できる。粥状硬化が僬展するとともに，動 脈収縮蛋白の活性は低下する（ことに $\mathrm{Ca}^{2+}$ 濃度 の変化による収縮調節能の低下) が，その初期に はこの蛋白の活性低下は軽いので前述の見解に大 きな矛盾はないと思われる。

\section{結 語}

1. 馬, 牛頸動脈, 人大動脈の主として中膜よ り収縮性蛋白, $\mathrm{My}-\mathrm{B}, \mathrm{My}, \mathrm{Ac}$ を分離抽出し, その性状, 特性を明らかにした。

2. 動脈収縮性蛋白の活性は弹状硬化の進展に つれて低下するが，とくに $\mathrm{Ca}^{2+}$ 濃度による収縮 調節能の低下が顕著であった。

3. 牛動脈平滑筋細胞, 人大動脈平滑筋細胞内 での Ac フィラメントを電顕的に同定するととも に，Myについては，本物質の家兔による抗体を 用い，間接法による peroxidase 標識電顕抗体法 で細胞内 $\mathrm{My}$ フィラメントを同定した。

4.人大動脈収縮蛋白も, 牛, 馬頸動脈収縮蛋 白と本質的に全く差異のない特性を示す．横紋筋 のものとはとくに My に打いて著明な差異のあ ることを知った。しかも動脈平滑筋細胞の収縮蛋 白, $\mathrm{My}, \mathrm{Ac}$ は遊走能を有する白血球の $\mathrm{My}, \mathrm{Ac}$ にも類似するので, その作動は単に収縮, 弛緩の 
みならず細胞間接合が解離すれば遊走細胞と同様 に細胞運動が起こる可能性を推測させた。

5. 以上の観点からコレステロール負荷初期に おける家兔大動脈の組織反応をみると，脂質の動 脈壁内への浸透に呼応して, 内膜に近い中膜表層 の平滑笳細胞の細胞間解離が起こって立ち上がり 現象を来し，健常時内膜面に並行に配列している 該細胞がその長軸を内膜面に垂直に向け遊走しつ つあるごとき像を得た。そして内膜への平滑筇細 胞の集積と，これらの細胞が脂肪滴を貧喰し顆粒 として細胞質に保持し，泡沫細胞と化すると解せ られる像が得られた。

6. 以上を要するに, 粥状硬化の成立, 進展に は血清脂質の動脈内膜への浸透を契機とし，これ を刺激源として動脈中膜平滑筋細胞の内膜面への 遊走が励起され，内膜に集積することが一義的な 意義を有するものと考它られる。

\section{文 献}

1) Ross, R. and Glomset, J.A.: A therosclerosis and the arterial smooth muscle cell. Science, 180: 1332 (1973).

2) Parker, F.: Electron microscopic study of experimental atherosclerosis. Am. J. Pathol., 36: 19 (1960).

3) Benditt, E. P.: Evidence for a monoclonal origin of human atherosclerotic plaques and some implications Circulation, 50:650 (1974).

4) Benditt, E.P. and Benditt, J.M.: Evidence for a monoclonal origin of humn atherosclerotic plaques. Proc. Nat. Acad. Sci,. 70: 1753 (1973).

5) Poole, J.C.F., Cromwell, S.B. and Benditt, E.P.: Behavior of smooth muscle cell and formation of extracellular structures in the reaction of arterial walls to injury. Am. J. Pathol., 62: 391 (1971).

6) 柴田宣彦, 山上 徹: 動脈壁収縮性蛋白の研究, 脈管学, 9: 176 (1969).

7) Shibata, N., Yamagami, T. and Akagami, H. et al.: Identification of myosin $\mathrm{A}$, actin and native tropomyosin constituting of arterial contractile protein (myosin B) and their characteristics, Jap. Circulation J., 37: 229 (1973).

8) Weber, K. and Osborn, M.: The reliability of molecular weight determinations by dodecyl sulfate-polyacrylamide gel electrophoresis. J. Biol. Chemist., 244: 4406 (1969).
9）柴田宣彦，巽 典之：血球成分の収縮性蛋白. 生体の科学, 24: 20 (1973).

10) Shibata, N. and Tatsumi, N. et al.: Leucocyte myosin and its location in the cell. Biochim. Bisphys. Acta, 400: 222 (1975).

11) Huxley, H.E.: Electron microscope studies on the structure of natural and synthetic protein filaments from striated muscle. J. Mol. Biol., 7: 281 (1963).

12) Ebashi, S.: Calcium binding activity of vesicular relaxing factor. J. Biochem. (Tokyo), 50: 236 (1961).

13) Martin, J.B. and Doty, D.M.: Determination of inoragnic phosphate. Modification of isobutylalcohol procedure. Analyt. Chemist., 21: 965 (1949).

14) Layne, E.: Spectrophotometric and turbidimetric methods for measuring proteinsBiuret method. Methods in Enzymology ed. by Colowick, S.P. and Kaplan, W.O. p.450, Acad. press, New York, (1957).

15) Senda, N., Tamura. H. and Shibata, N. et al.: The mechanism of the movement of leucocytes. Exp. Cell Res., 91: 393 (1975).

16) Ishikawa, H., Hishoff, R, and Holtzer, H.: Formation of arrowhead complexes with heavy meromyosin in a variety of cell types. J. Cell Biol., 43: 312 (1969).

17）東 昇，遠山 益：電子顕微鏡学実習. p. 84, 共立出版株式会社，東京 (1974).

18）鈴木郁男：酧素標識抗体法一とくに peroxidase 抗体法を中心として一。医学のあゆみ，76：419 (1971).

19）木村一郎: Ouchterlony 法. 免疫学，アレルギ 一学実験法. 進藤寅二監修 p. 266, 文光堂, 東京 (1971).

20) Graham, R,C. and Karnovsky, M.J.: The early stages of absorption of injected horseradish peroxidase in proximal tubles of mouse kidney: Ultrastructural cytochemistry by a new technique. J. Histochem. Cytochem., 14: 291 (1966).

21) Ostlund, R.E. and Pastan, I.: Myosin in cultured fibroblasts. J. Biol. Chemist., 249: 249 3903 (1974).

22) Stein, O. and Stein, Y.: Comparative uptake of rat and human serum low density and high density lipoproteins by rat aortic smooth muscle cell in culture. Circulation Res., 36: 436 (1975).

23) Tatsumi, N., Shibata, N. and Senda, N. et al.: Actin and myosin A from leucocytes. Biochim. Biophys. Acta, 305: 433 (1973).

24) Anitschikow, N.N. and Chalatov, S.: Zentralbl. Allg. Pathol., 24: 1 (1913). 


\section{収縮 蛋白}

25) Senda, N.: The mechanism of ingestion by phagocytosis. Recent Advances in RES Research, 10: 1 (1970).

26) Bierman, E.L., Stein, O. and Stein, Y.: Lipoprotein uptake and metabolism by rat aortic smooth muscle cells in tissue. culture, Cir- culation Res., 35: 136 (1974).

27) Bierman, E.L., Eisenberg, S., Stein, O. and Stein, Y.: Very low density lipoprotein "remnant" particles: Uptake by aortic smooth muscle cells in culture. Biochim. Biophys. Acta, 329: 163 (1973) 


\title{
Summary
}

\section{Contractile Protein-Motility of Arterial Smooth Muscle Cell and Atherosclerosis}

\author{
Nobuhiko SHIBATA and Akira WADA \\ The Center for Adult Diseases, Osaka
}

Histological investigation of medial smooth muscle cells in aorta of rabbits fed with cholesterol and biochemical study of contractile protein extracted from human atherosclerotic aortae stripping adventitia were reported in this paper. At the initial stage (within a week) of cholesterol feeding to rabbits, materials stained by Sudan III were observed histologically in the intima of aorta, suggesting that infiltration of lipid due to the cholesterol feeding to the aorta directly bathing with plasma. In the following early stage, smooth muscle cells in the media located adjacent to the intima, which were originally arranged parallel each other to the endothelial surface, were found to be arranged perpendicularly to the surface and to be going to migrate through intimal elastic lamina to the intima. After 1-2 weeks smooth muscle cells accumulated in the intima and they changed to so called "foam cells" probably due to phagocytosis of lipid.
And, it was demonstrated in electron microscopic study using Ishikawa's method that the migrating smooth muscle cells and the foam cells in the intima which are thought to be first cellular response in atherosclerosis contained intracellularly the characteristic myogenic filaments in a definite arrangement. Biochemical study of contractile protein extracted from atherosclerotic arteries clarified that myosin and actin content constituting the protein and the $\mathrm{Ca}^{2+}$ sensitivity of the protein decreased as the diseases advanced.

The evidence did support the idea as regard to the initial cause of pathogenesis of atherosclerosis that infiltration of lipid in plasma into the arterial wall may result in migration of the medial smooth muscle cells into the infiltrative area before subsequent histological manifestation of the disease.

Key words: Myosin, Actin, HMM (Haevymeromyosin), Arrowhead structure, Foam cell 